Przegląd Badań Edukacyjnych Educational Studies Review

ISSN 1895-4308

nr 20 (1/2015), s. 83-102

ORYGINALNE ARTYKULY BADAWCZE

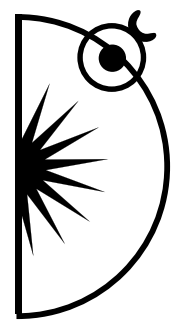

Małgorzata Kowalska

Uniwersytet Mikołaja Kopernika, e-mail: alkesta@wp.pl

\title{
Strategie dyscyplinowania dzieci stosowane przez rodziców nieheteroseksualnych i ich partnerów - studium przypadku
}

DOI: http://dx.doi.org/10.12775/PBE.2015.037

\section{Strategies for Disciplining Children Used by Non-heterosexual Parents and Their Partners - a Case Study}

\begin{abstract}
The article presents the results of a qualitative research conducted between 2010 and 2014. The participants of the study were non-heterosexual parents and their partners bringing up a child. The research problem concerned disciplining strategies. Data analysis and interpretation of the results was conducted in the context of the theory of moral development by L.M. Hoffman. Out of the seven cases analysed, evidence for the use of inductive discipline was found in two. Other participants combined either the strategy of induction and the powerassertive discipline, or the power-assertive discipline and the love-oriented discipline.
\end{abstract}

Key words: disciplining strategies, love-oriented discipline, power-assertive discipline, inductive discipline, LGBT parents, moral development, children of LGBT parents

\section{Wprowadzenie}

Pierwsze badania nad rodzinami gejów i lesbijek prowadzono w Stanach Zjednoczonych w II połowie lat 70. XX wieku (por. Tasker, Golombok, 1997; Golombok, 2002; Golombok i in., 2003). Początkowo przybierały one formę indywidualnych studiów przypadków nad samotnymi rodzicami homoseksualnymi 
i ich dziećmi. Stosowano w nich metody i narzędzia badań psychologicznych, tj. testy projekcyjne (Weeks, Derdeyn i Langman, 1975; Green, 1978), metodę wywiadu klinicznego (Green, 1978), metodę wywiadu częściowo ustrukturyzowanego (Miller, 1979). Głównie skupiano się w nich na rozwoju i doświadczeniach dzieci, a dokładniej na takich problemach, jak identyfikacja z rola płciową, rozwój intelektualny (Draw a Person Test, DAP), poczucie własnej wartości, orientacja seksualna, przystosowanie psychiczne (ang. psychological adjustment), molestowanie seksualne, doświadczenie ujawnienia się rodzica, relacje z rówieśnikami, stygmatyzacja. $\mathrm{W}$ odniesieniu do rodziców koncentrowano się na wykorzystywaniu dziecka (posiadanie dziecka jako sposób na ukrywanie lub rekompensowanie orientacji seksualnej rodzica), satysfakcji rodzica z relacji z dzieckiem, molestowaniu seksualnym dziecka, ujawnieniu orientacji seksualnej dziecku (Miller, 1979), koncepcji siebie (ang. self-concept) (Mucklow, Phelan, 1979).

W latach 80. zaczęto wprowadzać do badań nad rodzinami gejów i lesbijek grupę kontrolną w postaci samotnych heteroseksualnych matek i ojców i/ lub ich dzieci (Kirkpatrick, Smith, Roy, 1981; Miller i in., 1981; Hoeffer, 1981; Lewin, 1982; Hotveld, 1982; Golombok i in., 1983; Green i in., 1986; Harris i Turner, 1985; Steckel, 1987; Bigner i Jacobsen, 1989; Huggins, 1989). W badaniach tych mierzono takie zmienne, jak: zachowanie rodziców (Parent Behavior Inventory, PBI), relacje rodzica z dzieckiem (Kirkpatrick, Smith, Roy, 1981; Golombok, 1983). Natomiast w odniesieniu do dzieci badano rozwój emocjonalny (Golombok, 1983; Green, 1986), intelektualny (Green, 1986), relacje z rówieśnikami (Golombok, 1983), orientację seksualną (Golombok, 1983), dostosowanie psychiczne (Kirkpatrick, Smith, Roy, 1981; Golombok, 1983; Green, 1986; Steckel, 1987), rolę wynikającą z płci (Kirkpatrick, Smith, Roy, 1981; Golombok, 1983; Green, 1986; Harris, Turner, 1985; Hoeffer, 1981).

Jednym z pierwszych studiów porównujących rozwój dzieci wychowywanych przez homoseksualne i heteroseksualne matki były amerykańskie badania Marthy Kirkpatrick, Catherine Smith i Rona Roya (1981), mierzące takie zmienne, jak tożsamość płciowa i zaburzenia psychiczne u dzieci. W tym też czasie zostały zapoczątkowane w Wielkiej Brytanii przez Susan Golombok pierwsze, trwające 25 lat, badania podłużne nad rodzicielstwem lesbijek, w których badano związki między orientacją seksualną rodzica a zachowaniem, rolami płciowymi, zaburzeniami psychicznymi dzieci. Grupę kontrolną stanowiły rozwiedzione matki heteroseksualne (Tasker, Golombok, 1997). Autorka ta jako pierwsza śledziła zależność pomiędzy orientacją seksualną rodzica 
a orientacją seksualną i kształtowaniem się ról płciowych dziecka. Badała także jakość relacji dzieci z krewnymi, ojcem oraz rówieśnikami (Tomalski, 2007). Kierunek jej badań podyktowany był świadomością istnienia obaw społecznych dotyczących wychowywania dzieci przez osoby homoseksualne. Obawy te Golombok dzieli na trzy grupy. Pierwsza z nich dotyczy orientacji seksualnej dzieci wychowywanych przez pary jednopłciowe oraz podejmowania przez nie takiego typu zachowań, które niezgodne są ze społecznymi wzorcami płciowymi. Drugą stanowią przewidywane trudności dzieci w relacjach z otoczeniem, ryzyko stygmatyzacji i przemocy w stosunku do dzieci. Trzecia obejmuje obawy o wystąpienie u dzieci gejów i lesbijek emocjonalnych problemów w okresie dorosłości, jak również zaburzeń w sferze przyszłych związków miłosnych (Tomalski, 2007). Mówiąc ogólnie, obawy te dotyczą głównie funkcjonowania społecznego i psychicznego dzieci osób nieheteroseksualnych. Wydaje się, iż mimo kilku dekad, nie straciły one na aktualności (por. Prokopowicz, Slany, Kowalska, Śmietana, 2005).

W latach 80 . bez tworzenia grup kontrolnych badano orientację seksualną dzieci gejów i lesbijek, ich relacje rodzinne i rówieśnicze, a także przystosowanie psychiczne i role wynikające z płci (Bozett, 1980, 1987, 1988; Lewis, 1980; McCandlish, 1987; Wyers, 1987; Harris, Turner, 1985). W odniesieniu do matek lesbijek badano ich zdrowie psychiczne (ang. psychological health) (Rand, Graham, 1982) i doświadczanie przez nie społecznego wsparcia (Lewin, Lyons, 1982). W przypadku homoseksualnych ojców interesowano się sposobami i przyczynami ujawnienia przez nich orientacji seksualnej swoim dzieciom (Bozett, 1980).

Dalsze studia z lat 90. XX wieku prezentują szerszy wachlarz problemów badawczych. Poza badaniem identyfikacji płciowej dzieci (Gottman, 1990), ich ról płciowych (Gottman, 1990; Javaid, 1993), orientacji seksualnej, rozwoju psychospołecznego (Gottman, 1990; Golombok, Tasker, 1996, 1997; Tasker, Golombok, 1995), doświadczanej przez dzieci stygmatyzacji społecznej (Tasker, Golombok, 1995; Golombok, Tasker, 1996, 1997; Gershon, Tschann, Jemerin, 1999; Lewis, 1990; O’Connell, 1993) i, w jej kontekście, poczucia własnej wartości (Gershon, Tschann, Jemerin, 1999), coraz częściej podnoszono problematykę relacji wewnątrzrodzinnych. Szczególnie interesowano się relacjami między rodzicami a dziećmi (Brewaeys, 1997; Golombok i in., 2003) i satysfakcją z relacji między partnerami (Koepke, Hare, Moran, 1992; Patterson, 1995). Problematyka relacji rodzic-dziecko i rodzic-partner badana była w różnych kontekstach, m.in. w kontekście rozwoju nowych metod reprodukcji (Brewaeys i in., 1997; Chan, Raboy, Patterson, 1998; Vanfraussen, Ponjaert- 
-Kristoffersen, Brewaeys, 2001, 2002, 2003; Brewaeys i in., 1993, 1995; Gartell i in., 1996, 1999, 2000), a także w kontekście procesu ujawnienia orientacji seksualnej rodzica i rozwoju jego tożsamości seksualnej (Morris, Balsam, Rothblum, 2002; Joos, Broad, 2007; Baptist, Allen, 2008; Kuvulanka, Goldberg, 2009; Chirrey, 2003; Gershon, Tschann, Jemerin, 1999).

Na podstawie powyższego przeglądu można powiedzieć, iż w kontekście wychowania i socjalizacji dzieci przez osoby nieheteroseksualne interesowano się szczególnie rozwojem emocjonalnym, psychospołecznym i psychoseksualnym dzieci. Nie podejmowano jednak problemu strategii dyscyplinowania dzieci przez rodziców nieheteroseksualnych. Jak przekonuje Martin L. Hoffman, ,pod koniec drugiego roku życia dwie trzecie wszystkich interakcji rodzice-dziecko stanowią sytuacje dyscyplinowania dziecka, w których rodzice starają się zmienić zachowania dziecka wbrew jego woli" (Hoffman, 2006, s. 133). Natomiast „dzieci w wieku od dwóch do dziesięciu lat doświadczają rodzicielskich prób zmiany ich zachowania średnio co 6-9 minut, co daje około 50 sytuacji dyscyplinowania dziennie i ponad 15 tysięcy rocznie!" (Hoffman, 2006, s. 133). Wydaje się zatem, iż częstotliwość prób zmiany zachowania dziecka przez rodzica powinna zachęcić do podejmowania tego problemu w badaniach nad rozwojem dzieci wychowywanych przez rodziców nieheteroseksualnych.

W literaturze pedagogicznej i psychologicznej, niepoświęconej bezpośrednio problematyce rodzin tworzonych przez gejów i lesbijki, wskazuje się na związek pewnych obszarów rozwojowych ze strategiami (technikami) dyscyplinowania dzieci przez rodziców (zob. m.in. Hoffman, 1970, 1977, 1980, 1988; Maccoby, Martin, 1983; Stafford, Bayer, 1993; Izdebski, 1992; Baumrind, 1971, 1978, 1989, 1991; Darling, Steinberg, 1993). Jak zauważa Rudolph H. Schaffer, „choć sposób, w jaki rodzice skłaniają dzieci do podejmowani określonych form zachowań, sam w sobie jest interesującym tematem, to jego poznanie może również prowadzić do lepszego zrozumienia dziecka jako osoby, która sama kontroluje swoje zachowania zgodnie z normami moralnymi" (Schaffer, 1996, s. 279). Dlatego też, zdaniem autorki niniejszej pracy, ważne jest prowadzenie nie tylko badań nad poziomem (etapem) rozwoju dzieci wychowywanych w związkach homoseksualnych jako efektem oddziaływań wychowawczych i socjalizacyjnych, ale także nad samymi strategiami dyscyplinowania dziecka. Szczególnie wartościowe wydają się w tym kontekście badania podłużne, mierzące wiele zmiennych, w tym techniki kontroli rodzicielskiej. 


\section{Techniki dyscyplinowania dziecka a konsekwencje rozwojowe}

Technika dyscyplinowania (technika kontroli) jest to zespół zachowań podejmowanych przez osobę w celu zmiany aktualnego sposobu zachowania innej osoby. „Ich funkcją jest zahamowanie pewnych tendencji i wzmocnienie innych. Techniki kontroli ukierunkowane są zwykle na osiagnnięcie natychmiastowych, nie zaś odległych w czasie skutków [...]. Możliwe jednak, że codzienna i ciagła kontrola prowadzi także do trwałych efektów" (Schaffer, 1996, s. 282). Techniki te określane są niekiedy technikami kontroli bądź stylem kierowania wychowawczego.

Zależność między zmienną stylu kierowania wychowawczego rodziców i partnerstwem w związku rodziców a czasem inicjacji seksualnej młodzieży badał Zbigniew Izdebski. Większość badanych $(\mathrm{N}=3175)$ była w wieku między 19 a 23 rokiem życia. Styl kierowania wychowawczego mierzono na postawie oceny respondentów dotyczącej zachowania ich rodziców określonych jako: ,wymagający - ostry”, ,wymagający - życzliwy”, ,niewymagający”, „,niekonsekwentny”, „nieinterweniujący”. Z badań tych wynika, iż w przypadku dziewcząt moment podejmowania przez nie inicjacji seksualnej ma związek ze stylem kierowania wychowawczego matki i ojca. W przypadku chłopców natomiast nie wykazano takiego związku. W przypadku dziewcząt połowa z nich $(\mathrm{N}=1310)$ określiła zachowanie swoich matek jako wymagające i życzliwe. Ze wszystkich przebadanych dziewcząt $83,4 \%$ przyznaje się do odbytej inicjacji seksualnej po osiągnięciu pełnoletniości; $61,5 \%$ ocenia zachowania swoich matek wobec nich jako wymagające i życzliwe. Natomiast „wśród osób, które odbyły pierwszy stosunek płciowy przed ukończeniem osiemnastego roku życia, było 49,3\%, takich, które miały wymagającą i życzliwą zarazem matkę" (Izdebski, 1992, s. 31). W przypadku zachowania ojców w stosunku do ich córek stwierdzono, iż ,relatywnie rzadziej podejmują życie płciowe przed pełnoletniością te dziewczęta, których ojcowie byli wobec nich wymagający i życzliwi oraz niewymagający; częściej natomiast zdarzało się to w przypadku córek ojców wymagających i ostrych, niekonsekwentnych i nieinterweniujących" (Izdebski, 1992, s. 31). Dodatkowo badania te wykazały, iż te dziewczęta, które oceniały relacje swoich rodziców jako partnerskie, rzadziej podejmowały wczesną aktywność seksualną. Częściej miały inicjację seksualną przez ukończeniem osiemnastego roku życia te dziewczęta, które miały dominujące matki. Zmienna partnerstwa związku ojca i matki nie miała również znaczenia w przypadku chłopców (Izdebski, 1992, s. 31).

Związek między rozwojem kompetencji prospołecznych dzieci a wychowaniem przez rodziców badali m.in. Carolyn Zahn-Waxler, Marian Radke-Yar- 
row, Robert A. King (1979) i Joann L. Robinson, Carolyn Zahn-Waxler i Robert Emde (1994) (za: Schaffer, 1996). Badania te wykazały, iż jednym z typów zachowań mających związek z rozwojem skłonności prospołecznych u dzieci jest dostarczanie dziecku jasnych reguł i zasad. „,...] Matki, które zrozumiale wyrażały obowiązujące reguły zachowania (np. „Nie bij innych!”), a ponadto w prosty sposób mówiły o konsekwencjach działań dziecka („Jeśli uderzysz Susan, będzie ją bolało"), w największym stopniu sprzyjały rozwojowi jego skłonności prospołecznych. $\mathrm{W}$ ten sposób dziecku dostarczane są bowiem wskazówki, które może przenosić na inne sytuacje, podczas gdy nie ma takiej możliwości w przypadku niedookreślonych zakazów, które są np. podane bez wyjaśnienia (np. „Nie rób tego!”) (Schaffer, 1996, s. 307-308).

Zależność pomiędzy strategiami (technikami) dyscyplinowania dzieci a rozwojem moralnym (internalizacja norm moralnych) badał m.in. M. L. Hoffman (Hoffman, 1970, 1977, 1980; Hoffman, Salzstein, 1967). Wyróżnił on trzy grupy technik dyscyplinowania dzieci.

- Wycofanie miłości (ang. love-oriented discipline) - w celu skłonienia dziecka do stosowania się do nakazów rodzice korzystający z tej metody wycofują swoje uczucia i aprobatę za każdym razem, gdy dziecko zachowuje się w sposób niewłaściwy. Do zachowań rodziców wskazujących na stosowanie tej strategii należą np. ignorowanie dziecka, odwracanie się do niego tyłem, nieodzywanie się do niego, odmawianie rozmowy z dzieckiem, nie słuchanie go, wyrażanie wprost niechęci, izolowanie dziecka bądź straszenie, iż będzie zostawione.

- Przejawianie siły (ang. power-assertive discipline) - bezwarunkowe wyrażanie przez rodzica swej wyższości nad dzieckiem. Są to np. kary fizyczne, wstrzymywanie przywilejów, werbalne formy narzucania swej woli.

- Indukcja (ang. inductive discipline) - wyjaśnianie dziecku przyczyn, dla których wymaga się od niego określonego sposobu zachowania, podawanie dziecku uzasadnień, wyjaśnień w celu skłonienia dziecka do stosowania się do nakazów. Ta technika apeluje do rozumowania dziecka (patrz m.in. Hoffman, 2006; Spera, 2005; Eisenberg, Morris, 2001; Schaffer, 1996). Jest to metoda, „w której rodzice podkreślają punkt widzenia drugiej strony, wskazują na cierpienia innych oraz akcentuja fakt, że zostały one spowodowane działaniem dziecka" (Hoffman, 2006, s. 135).

Autor tej koncepcji przyjmuje, iż większość rodziców stosuje wszystkie techniki dyscyplinowania dzieci. Pojedyncza sytuacja, w której dziecko jest 
dyscyplinowane, może zawierać elementy każdej z nich. M. L. Hoffman uznaje jednak, iż istnieją stałe różnice w zakresie, w jakim pewni rodzice wolą stosować dany rodzaj technik, niż odnosić się do dwóch pozostałych. Zdaniem Hoffmana różnice te mają związek z rozwojem empatii obserwowanym u dzieci. Częste korzystanie przez rodziców z metod indukcji wiąże się z dojrzałością moralną u dzieci. Dotyczy to szczególnie indukcji ,zorientowanej na innych”. Obejmuje ona taki rodzaj uzasadnień, które pokazują dziecku, jaki jest wpływ jego zachowania na innych ludzi. Indukcja najskuteczniej prowadzi do internalizacji przez dziecko standardów moralnych. Dominacja dyscyplinowania przez przejawianie siły częściej rozwija u dzieci orientację moralną opartą na strachu przed karą i byciem „wykrytym”, „przyłapanym”. Zachowanie opiera się na sankcjach zewnętrznych, a nie na wewnętrznych standardach. Jak pisze M. L. Hoffman, „,zęste stosowanie takich metod sprawia, że dzieci okazują posłuszeństwo ze strachu, ale wyrażają swój gniew i skłonności opozycyjne wobec postaci dysponujących mniejszą władzą, na przykład rówieśników lub wychowawców w przedszkolu" (Hoffman, 2006, s. 138). Częste wycofywanie miłości jako reakcja na brak posłuszeństwa u dzieci nie ma jednoznacznego wpływu na orientację moralną dziecka. Jednak podaje się, iż powodować może u szczególnie zależnych dzieci silne przerażenie i stanowić silny bodziec do przestrzegania nakazów rodzicielskich (Hoffman, 2006; Schaffer, 1996). „Wycofanie miłości w większym stopniu niż podkreślenie władzy wykorzystuje pełną uczucia więź łączącą dziecko z rodzicami, ale równie często wywołuje szkodliwą reakcję lękową - nie gniew i strach, ale właśnie lęk o to, czy rodzicowi wciąż zależy na dziecku" (Hoffman, 2006, s. 140). Skutki wycofywania miłości i przejawiania siły można jednak łagodzić przez stosowanie wyjaśnień, które Hoffman nazywa „amortyzatorami”. Sytuują one żądania rodziców w pozycji zjawiska znajdującego się poza kontrolą rodzica. Rodzic zatem w wyjaśnieniach może odwołać się do czegoś niezależnego od niego (,Jeśli będziesz dla niego niemily, on też może być niemiły dla ciebie") (Hoffman, 2006, s. 139). Autor ten zaznacza także, iż bezwarunkowe podkreślanie władzy jest czasami niezbędne, na przykład w nagłych sytuacjach, kiedy nie ma możliwości innego działania. Może być działaniem konstruktywnym, zwłaszcza gdy rodzic nie często z takiej metody korzysta. Hoffman pisze, iż „,czasami bezwarunkowe podkreślenie władzy może być dla rodziców zwykle stosujących indukcję najlepszym sposobem, by zakomunikować, głośno i wyraźnie, pozytywną wartość przyznawaną przez nich szanowaniu dobra innych oraz by wyrazić szczególnie negatywne emocje, jakie odczuwają w związku z określonymi szkodliwymi działaniami” (Hoffman, 2006, s. 140). 
Niektórzy autorzy wskazują także na inne czynniki mogące mieć, poza technikami dyscyplinowania, związek z rozwojem moralności u dzieci. Są to m.in. indywidualne cechy dziecka (np. Kochańska, 1991, za: Schaffer, 1996, s. 345) bądź elastyczność rodziców w stosowaniu i przekazywaniu panujących zasad i oczekiwań (Grusec, Goodnow, 1994, za: Schaffer, 1996, s. 345).

Strategia kontroli rodzicielskiej ma zatem, zdaniem Hoffmana, związek z rozwojem empatii u dzieci. Empatia jest to „reakcja afektywna, bardziej adekwatna do sytuacji, w jakiej jest inna osoba, aniżeli do sytuacji jednostki, która przejawia tę reakcję. A zatem dziecko wykazuje empatię, kiedy jest smutne, gdy inna osoba jest smutna, i kiedy cieszy się, gdy cieszy się ktoś inny" (Schaffer, 1996, s. 302). Hoffman uznawał, iż „najważniejszym warunkiem reakcji empatycznej jest zaangażowanie procesów psychicznych sprawiających, że dana osoba odczuwa emocje, które bardziej pasują do sytuacji innej osoby niż do jej własnej” (Hoffman, 2006, s. 38). Autor ten zwracał szczególną uwagę na rozumienie i tym samym definiowanie empatii w kategoriach procesualnych. Wyróżnił on następujące stadia rozwoju empatii.

Tabela 1. Stadia rozwoju empatii wg L. M. Hoffmana. Opracowanie własne za: Schaffer, 1996; L. M. Hoffman, 2006.

\begin{tabular}{|c|c|c|}
\hline Studium & Początek studium & Charakterystyka \\
\hline Empatia globalna & Pierwszy rok życia & $\begin{array}{l}\text { Dziecko nie postrzega innych ludzi } \\
\text { jako odrębnych od "ja". Smutek } \\
\text { innych bywa mylony ze smutkiem } \\
\text { odczuwanym przez dziecko. }\end{array}$ \\
\hline Empatia „egocentryczna” & Drugi rok życia & $\begin{array}{l}\text { Dziecko wie już, iż to inna osoba } \\
\text { cierpi, a nie ono. Stany wewnętrz- } \\
\text { ne innych uznaje nadal za takie } \\
\text { same jak własne. }\end{array}$ \\
\hline $\begin{array}{l}\text { Empatia odnosząca się do uczuć } \\
\text { innych osób }\end{array}$ & $\begin{array}{c}\text { Między trzecim a czwartym rokiem } \\
\text { życia }\end{array}$ & $\begin{array}{l}\text { Dziecko przestaje reagować na } \\
\text { uczucia innych osób egocentrycz- } \\
\text { nie. Jest już świadome, iż inni } \\
\text { mogą mieć własne uczucia, różnią- } \\
\text { ce się od uczuć dziecka. }\end{array}$ \\
\hline $\begin{array}{l}\text { Empatia w zakresie sytuacji } \\
\text { życiowej innych }\end{array}$ & Późne dzieciństwo & $\begin{array}{l}\text { Uczucia innych dziecko postrzega } \\
\text { jako skutek i wyraz całościowego } \\
\text { doświadczenia danej osoby, a nie } \\
\text { jako chwilową reakcję. Reakcje } \\
\text { dziecka na krótkotrwały i długo- } \\
\text { trwały smutek innej osoby są inne. } \\
\text { Emocje dziecka wzbudzone w spo- } \\
\text { sób empatyczny są powiązane } \\
\text { z umysłową reprezentacją sytuacji, } \\
\text { w której znajduje się inna osoba. }\end{array}$ \\
\hline
\end{tabular}


Małgorzata Kowalska Strategie dyscyplinowania dzieci stosowane przez rodziców...

\section{Metoda}

Przedmiotem omawianego badania było sześcioro rodziców nieheteroseksualnych żyjących w związku jednopłciowym (w tym pięć kobiet i jeden mężczyzna) i jedna homoseksualna partnerka matki. Wiek badanych mieścił się w przedziale od 31 do 40 lat. Wiek dzieci natomiast od 2,5 do 17 lat. Problemem badawczym była technika dyscyplinowania dziecka stosowana przez rodzica/ów i partnerkę. Badanie mieści się w strategii jakościowej, typie eksploracyjno-weryfikacyjnym, schemacie zbiorowego studium przypadku z jego odmianą praktyczno-diagnostyczną. W prezentowanym badaniu zastosowano metodologię teorii ugruntowanej, polegająca na „budowaniu teorii (średniego zasięgu) w oparciu o systematyczne zbierane dane empiryczne" (Konecki, Chomczyński, 2012, s. 177).

Metodą zbierania danych był częściowo kierowany wywiad narracyjny indywidualny i grupowy. Wywiad grupowy w niniejszej pracy oznacza wywiad przeprowadzony z para badanych (rodzicem i partnerem/partnerka). Zastosowano go w przypadku braku zgody badanych na udzielenie wywiadu indywidualnego bądź braku warunków na jego przeprowadzenie (np. konieczność wspólnej opieki nad dzieckiem). Kryterium doboru próby był charakter związku (związek jednopłciowy), biologiczne pokrewieństwo z dzieckiem/ dziećmi, mieszkanie w Polsce. W badaniu zarówno tożsamość seksualna, jak i tożsamość płciowa mierzona jest na podstawie autoidentyfikacji badanych. Jeśli zatem badany określa siebie jako lesbijkę, badacz przyjmuje, iż ta osoba jest lesbijką. Jeśli określa, iż jest kobietą, badacz przyjmuje, iż dana osoba jest kobietą. Związek jednopłciowy rozumiany jest zatem również jako związek osób tej samej płci biologicznej, bądź/lub psychicznej. W niniejszym badaniu wiek dziecka nie stanowił kryterium doboru próbki badawczej. Nieustanawianie takiego kryterium spowodowane było bardzo trudnym dostępem do badanych. Próba badawcza została dobrana w sposób nielosowy celowy (metoda incydentalna). Badanych poszukiwano metodą śnieżnej kuli. Prezentowane dane zostały zebrane w latach 2010-2014 w ramach badań do pracy doktorskiej.

Analizie zostały poddane wypowiedzi siedmiu nieheteroseksualnych badanych - pięciu matek, jednej partnerki matki i jednego ojca. Wypowiedzi obejmowały zarówno opis sytuacji, które miały miejsce w niedalekiej przeszłości, ale także hipotetyczne, przewidywane reakcje rodzica bądź partnera na zachowanie dziecka. Badani zatem odpowiadali na pytanie, jak zachowaliby się w określonej sytuacji. Niekiedy, w trakcie przeprowadzonego wywiadu, problem strategii dyscyplinowania dzieci pojawiał się spontanicznie, bez konieczności nakierowania badanego. Wówczas dopytywany był on o szczegóły. 
Analiza danych składała się z trzech etapów: redukcji danych (kodowania) i reprezentacji danych, weryfikacji. Metodą kodowania danych była analiza treści, w której kategorie analityczne wyprowadzane są nie z materiału empirycznego, a z koncepcji badania. Kategorie analityczne zostały wypracowane $\mathrm{z}$ koncepcji rozwoju moralnego Hoffmana, a dokładnie z wyodrębnionych przez niego technik dyscyplinowania dzieci. W ramach reprezentacji zastosowano sekwencyjną analizę dyskursywną i szacowanie współwystępowania. Metodą weryfikacji była triangulacja badaczy.

\section{Analiza}

Tabela 2. przedstawia wybrane fragmenty wypowiedzi, które uznano za reprezentatywne w kontekście podejmowanej problematyki. Poniższa prezentacja ma zatem na celu zilustrowanie metody i sposobu kodowania danych.

Tabela 2. Kodowanie danych. Opracowanie własne

\begin{tabular}{|c|c|c|c|c|}
\hline $\mathrm{Nr}$ & Jednostka analizy & $\begin{array}{l}\text { Wycofanie } \\
\text { miłości }\end{array}$ & $\begin{array}{l}\text { Przejawianie } \\
\text { siły }\end{array}$ & Indukcja \\
\hline \multicolumn{5}{|c|}{$\begin{array}{c}\text { Badana nr } 1 \\
\text { Matka o tożsamości lesbijskiej żyjąca z kobietą transseksualną. Wiek - } 40 \text { lat, syn dwuipółroczny. Syn } \\
\text { od urodzenia wychowywany w związku osób nieheteroseksualnych. Partnerką matki jest transseksualna } \\
\text { kobieta o tożsamości homoseksualnej. }\end{array}$} \\
\hline 1 & $\begin{array}{l}\text { Ważne jest, aby z dzieckiem rozmawiać i ob- } \\
\text { jaśniać mu świat, który widzi. }\end{array}$ & Nie & Nie & $\begin{array}{c}\text { Tak } \\
\text { Wyjaśnianie przy- } \\
\text { czyn, apelowanie } \\
\text { do rozumowania } \\
\text { dziecka. }\end{array}$ \\
\hline 2 & $\begin{array}{l}\text { Ważne jest, aby dziecku klarować obraz } \\
\text { świata, tłumaczyć, uświadamiać. }\end{array}$ & Nie & Nie & $\begin{array}{c}\text { Tak } \\
\text { Wyjaśnianie przy- } \\
\text { czyn, apelowanie } \\
\text { do rozumowania } \\
\text { dziecka. }\end{array}$ \\
\hline 3 & $\begin{array}{l}\text { Nie chcemy, żeby było tak, żeby myślał, że } \\
\text { ma wyrzucić śmieci, bo tak się robi i koniec, } \\
\text { co sobie przypominamy z własnego wy- } \\
\text { chowania. Rodzice nie podejmowali z nami } \\
\text { dyskusji "dlaczego?". Formułuje to człowieka } \\
\text { w taki sposób, do takiego automatycznego } \\
\text { wykonywania czynności i braku krytycznego } \\
\text { myślenia, z możliwością lenistwa i świado- } \\
\text { mością, że się zawsze można wymigać. }\end{array}$ & Nie & Nie & $\begin{array}{c}\text { Tak } \\
\text { Wyjaśnianie przy- } \\
\text { czyn, apelowanie } \\
\text { do rozumowania } \\
\text { dziecka. }\end{array}$ \\
\hline
\end{tabular}


Tabela 2. Cd.

\begin{tabular}{|c|c|c|c|c|}
\hline \multicolumn{5}{|c|}{$\begin{array}{c}\text { Badana nr } 2 \\
\text { Matka o tożsamości biseksualnej żyjąca od } 4 \text { lat z kobietą. Wiek - } 34 \text { lata. Córka - } 14 \text { lat, od } 4 \text { lat żyjąca } \\
\text { z matką i jej partnerką, a także ojcem i jego partnerką (opieka naprzemienna). }\end{array}$} \\
\hline 1 & $\begin{array}{l}\text { Zawsze starałam się jej wszystko tłumaczyć, } \\
\text { nawet to, dlaczego ma posprzątać pokój - } \\
\text { bo przyjdą koleżanki i jak to będzie wyglą- } \\
\text { dało? }\end{array}$ & Nie & Nie & $\begin{array}{c}\text { Tak } \\
\text { Apelowanie do } \\
\text { rozumowania } \\
\text { dziecka, orientacja } \\
\text { na innych. }\end{array}$ \\
\hline 2 & $\begin{array}{l}\text { Czasami grymasiła i nie chciała czegoś zro- } \\
\text { bić, ale jak się ją trochę poprzekonywało to } \\
\text { się udawało. }\end{array}$ & Nie & Nie & $\begin{array}{c}\text { Tak } \\
\text { Wyjaśnianie przy- } \\
\text { czyn, apelowanie } \\
\text { do rozumowania } \\
\text { dziecka. }\end{array}$ \\
\hline 3 & $\begin{array}{l}\text { Kiedyś coś chciała wymóc, że "tato mi po- } \\
\text { zwala". Ja na to: "Tak? To ja już dzwonię } \\
\text { i sprawdzam", a ona: „O Jezu, bo wy musicie } \\
\text { mieć taki wspólny front przeciwko mnie". }\end{array}$ & Nie & Nie & $\begin{array}{c}\text { Tak } \\
\text { Wspólne zasady } \\
\text { stosowane przez } \\
\text { obojga rodziców, } \\
\text { konsekwencja } \\
\text { indukcji. }\end{array}$ \\
\hline 4 & $\begin{array}{l}\text { Myślę, że już ma tak wpojone zasady, że nie } \\
\text { trzeba dużo mówić. }\end{array}$ & Nie & Nie & $\begin{array}{l}\text { Tak } \\
\text { Konsekwencja } \\
\text { indukcji. }\end{array}$ \\
\hline \multicolumn{5}{|c|}{$\begin{array}{c}\text { Badana nr } 3 \\
\text { Matka o tożsamości lesbijskiej żyjąca od półtora roku z kobietą. Wiek - } 37 \text { lat. Wiek jej dwóch córek - } 7 \\
\text { i } 8 \text { lat. Wiek syna partnerki - } 3 \text { lata. Córki mieszkają z matką, partnerką matki i jej synem. Wypowiedzi } \\
\text { dotyczą technik dyscyplinowania wszystkich dzieci (zarówno własnych córek, jak i syna partnerki). }\end{array}$} \\
\hline 1 & $\begin{array}{l}\text { Ponieważ one jedzą jak małe świnki, to po- } \\
\text { wiedziałam, że kto najbardziej nabrudzi, to } \\
\text { będzie po sobie sprzątał. }\end{array}$ & Nie & $\begin{array}{l}\text { Tak } \\
\text { Werbalna forma } \\
\text { narzucania swej } \\
\text { woli. }\end{array}$ & Nie \\
\hline 2 & $\begin{array}{l}\text { Ja to mam taki stosunek - nie to nie, jak ci } \\
\text { przejdzie, to pogadamy. Chyba, że mnie bar- } \\
\text { dzo wkurzy, to na nią nawrzeszczę. Ale one } \\
\text { to już nie reagują na to. }\end{array}$ & $\begin{array}{l}\text { Tak } \\
\text { Wyrażanie } \\
\text { niechęci. }\end{array}$ & $\begin{array}{l}\text { Tak } \\
\text { Werbalna forma } \\
\text { narzucania swej } \\
\text { woli. }\end{array}$ & Nie \\
\hline 3 & $\begin{array}{l}\text { Ostatnio sprzątałam po nich zabawki i po- } \\
\text { wiedziałam: „Koniec! Ostatni raz sprzątam te } \\
\text { zabawki! Następnym razem jak posprzątam } \\
\text { zabawki, to albo wylądują w koszu, albo od- } \\
\text { dam innym biednym dzieciom”. }\end{array}$ & $\begin{array}{c}\text { Tak } \\
\text { Straszenie. }\end{array}$ & $\begin{array}{l}\text { Tak } \\
\text { Werbalna forma } \\
\text { narzucania swej } \\
\text { woli. }\end{array}$ & Nie \\
\hline 4 & $\begin{array}{l}\text { Wchodzę wieczorem do domu, jest pora } \\
\text { kąpieli, mówię: „0 nie! Nie pójdziecie spać, } \\
\text { najpierw sprzątanie!". }\end{array}$ & $\begin{array}{c}\text { Tak } \\
\text { Straszenie. }\end{array}$ & $\begin{array}{c}\text { Tak } \\
\text { Werbalna forma } \\
\text { narzucania swej } \\
\text { woli. }\end{array}$ & Nie \\
\hline 5 & $\begin{array}{l}\text { Nie za bardzo są zachwyceni, ale jak coś po- } \\
\text { wiem, to muszą to zrobić. }\end{array}$ & Nie & $\begin{array}{c}\text { Tak } \\
\text { Werbalna forma } \\
\text { narzucania swej } \\
\text { woli. }\end{array}$ & Nie \\
\hline
\end{tabular}


Tabela 2. Cd.

\begin{tabular}{|c|c|c|c|c|}
\hline \multicolumn{5}{|c|}{$\begin{array}{c}\text { Badana nr } 4 \text { (partnerka badanej nr 3) } \\
\text { Matka o tożsamości biseksualnej żyjąca od półtora roku z kobietą. Wiek - } 34 \text { lata, wiek jej syna - } 3 \text { lata, } \\
\text { dzieci partnerki - dwie córki w wieku } 7 \text { i } 8 \text { lat. Matka ta mieszka z synem, razem ze swoją partnerką i jej } \\
\text { dwiema córkami. Wypowiedzi dotyczą technik dyscyplinowania wszystkich dzieci (zarówno córek partner- } \\
\text { ki, jak i własnego syna). }\end{array}$} \\
\hline 1 & $\begin{array}{l}\text { Jak czegoś nie chcą zrobić, wrzeszczę na nie. } \\
\text { Mnie się boją. }\end{array}$ & Nie & $\begin{array}{l}\text { Tak } \\
\text { Werbalna forma } \\
\text { narzucania swej } \\
\text { woli, krzyk. }\end{array}$ & Nie \\
\hline 2 & $\begin{array}{l}\text { Nie słuchają się. Kuchnia musi być zamykana } \\
\text { w następnym mieszkaniu i pokój nasz też. }\end{array}$ & $\begin{array}{l}\text { Tak } \\
\text { Izolowanie } \\
\text { dziecka. }\end{array}$ & Nie & Nie \\
\hline 3 & $\begin{array}{l}\text { Kuchnia musi być zamykana, kręcą się pod } \\
\text { nogami, jak się smaży kotlety. }\end{array}$ & $\begin{array}{l}\text { Tak } \\
\text { Izolowanie } \\
\text { dziecka. }\end{array}$ & Nie & Nie \\
\hline \multicolumn{5}{|c|}{$\begin{array}{c}\text { Badany nr } 5 \\
\text { Ojciec o tożsamości homoseksualnej. Wiek - } 34 \text { lata. Od } 5 \text { lat żyjący w związkach jednopłciowych. Wiek } \\
\text { córki - } 12 \text { lat. Kontakt z córką - codzienny, telefoniczny, odwiedziny w weekendy i w czasie ferii (zimo- } \\
\text { wych i letnich). }\end{array}$} \\
\hline 1 & $\begin{array}{l}\text { Gdyby moja córka nie chciała sprzątnąć } \\
\text { ubrań, powiedziałbym, że nigdzie nie pój- } \\
\text { dziemy. }\end{array}$ & $\begin{array}{c}\text { Tak } \\
\text { Straszenie. }\end{array}$ & $\begin{array}{l}\text { Tak } \\
\text { Werbalna forma } \\
\text { narzucania } \\
\text { swej woli, } \\
\text { wstrzymywanie } \\
\text { przywilejów. }\end{array}$ & Nie \\
\hline 2 & $\begin{array}{l}\text { Jeśli moja córka nie chciałaby czegoś zrobić, } \\
\text { powiedziałbym, że skoro ty nie chcesz mnie } \\
\text { słuchać, to ja nie będę chciał robić tego, co } \\
\text { ty będziesz chciała. }\end{array}$ & $\begin{array}{c}\text { Tak } \\
\text { Straszenie. }\end{array}$ & $\begin{array}{l}\text { Tak } \\
\text { Werbalna forma } \\
\text { narzucania swej } \\
\quad \text { woli. }\end{array}$ & Nie \\
\hline \multicolumn{5}{|c|}{ 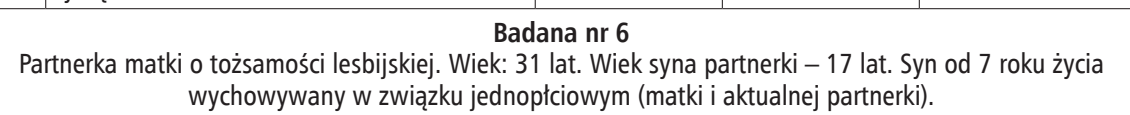 } \\
\hline 1 & $\begin{array}{l}\text { Skoro odkurzasz u siebie, to mógtbyś też od- } \\
\text { kurzyć u nas. }\end{array}$ & Nie & $\begin{array}{l}\text { Tak } \\
\text { Werbalna forma } \\
\text { narzucania swej } \\
\text { woli. }\end{array}$ & Nie \\
\hline 2 & $\begin{array}{l}\text { Mówiłam mu, żeby też u nas odkurzał [...], } \\
\text { bo jak ja byłam w jego wieku, to musiałam } \\
\text { odkurzać. }\end{array}$ & Nie & $\begin{array}{c}\text { Tak } \\
\text { Werbalna forma } \\
\text { narzucania swej } \\
\text { woli. }\end{array}$ & Nie \\
\hline 3 & $\begin{array}{l}\text { Teraz ty musisz pomagać nosić cięższe zaku- } \\
\text { py, bo ja jestem po operacji kręgosłupa i nie } \\
\text { mogę dźwigać. }\end{array}$ & Nie & $\begin{array}{l}\text { Tak } \\
\text { Werbalna forma } \\
\text { narzucania swej } \\
\text { woli. }\end{array}$ & $\begin{array}{l}\text { Tak } \\
\text { Wyjaśnianie przy- } \\
\text { czyn, apelowanie } \\
\text { do rozumowania } \\
\text { dziecka, orientacja } \\
\text { na innych. }\end{array}$ \\
\hline
\end{tabular}


Tabela 2. Cd.

\begin{tabular}{|c|c|c|c|c|}
\hline \multicolumn{5}{|c|}{$\begin{array}{c}\text { Badane nr } 7 \\
\text { Wspólna wypowiedź matki i jej partnerki. Wiek matki }-34 \text { lata, partnerki }-27 \text {. Wiek syna }-5 \text { lat. Dziecko } \\
\text { wychowywane od urodzenia w związku jednopłciowym. }\end{array}$} \\
\hline 1 & $\begin{array}{l}\text { Szukamy przyczyn odmowy, wtedy rozma- } \\
\text { wiamy. }\end{array}$ & Nie & Nie & $\begin{array}{c}\text { Tak } \\
\text { Apelowanie do } \\
\text { rozumowania } \\
\text { dziecka. }\end{array}$ \\
\hline 2 & $\begin{array}{l}\text { Zna swoje obowiązki domowe, oczywiście } \\
\text { adekwatne do wieku. Zatem kiedy oczekuję, } \\
\text { że sprzątnie po sobie po posiłku, w przypad- } \\
\text { ku gdy zapomni, wystarczy przypomnienie } \\
\text { zasady (np. „Po posiłku odnosimy po sobie } \\
\text { talerze") lub krótkie hasło (np. „Talerz"). }\end{array}$ & Nie & Nie & $\begin{array}{l}\text { Tak } \\
\text { Apelowanie do } \\
\text { rozumowania } \\
\text { dziecka (przypo- } \\
\text { minanie znanej } \\
\text { mu zasady). }\end{array}$ \\
\hline 3 & $\begin{array}{l}\text { Tylko dziecko, które zje cały obiad, będzie } \\
\text { mogło wyciągnąć słodycz ze swojej szuflady. }\end{array}$ & Nie & $\begin{array}{c}\text { Tak } \\
\text { Werbalna forma } \\
\text { narzucania swej } \\
\text { woli. }\end{array}$ & Nie \\
\hline 4 & $\begin{array}{l}\text { Trzymamy się zasady, że dziecko musi czuć, } \\
\text { że te same zasady obowiązują wszystkich } \\
\text { członków rodziny, stąd każdy ma obowiązki. }\end{array}$ & Nie & Nie & $\begin{array}{c}\text { Tak } \\
\text { Apelowanie do } \\
\text { rozumowania } \\
\text { dziecka, wyjaśnia- } \\
\text { nie przyczyn. }\end{array}$ \\
\hline
\end{tabular}

M. L. Hoffman, budując teorię na podstawie swoich badań, w której także techniką zbierania danych był wywiad, zauważał ograniczenia metodologiczne. Dotyczą one możliwości opisywania przez rodziców swoich zachowań w sposób zniekształcony, mając na celu lepsze zaprezentowanie siebie podczas wywiadu („efekt potrzeby aprobaty społecznej”) (zob. Schaffer, 1996, s. 344). Zaprezentowana analiza wskazuje, iż nie wszyscy rodzice wyrażali komunikaty świadczące o stosowaniu strategii indukcyjnej, która, w świetle omawianych konsekwencji rozwojowych, uznawana jest za najbardziej korzystną. Spośród siedmiu analizowanych przypadków, zaprezentowane wypowiedzi dwóch badanych świadczą o stosowaniu techniki indukcyjnej (Badany 1 i 2). Pozostali badani łączyli strategię indukcyjną i przejawianie siły (Badany 6 i 7) lub przejawianie siły i wycofanie miłości (Badany 3, 4 i 5). Niewykluczone jednak, iż, zgodnie z sugestiami Hoffmana, każdy z badanych stosował w swoim oddziaływaniu socjalizacyjnym i wychowawczym wszystkie omówione strategie. $\mathrm{Na}$ podstawie niniejszych badań można jedynie przypuszczać, iż zidentyfikowana na bazie wypowiedzi badanych strategia, była, jest i będzie tą najczęściej stosowaną. Również w kategoriach przypuszczeń można mówić o kierunku rozwoju moralnego dzieci wychowywanych przez osoby nieheteroseksualne. Zgodnie 
z koncepcją L. M. Hoffmana, dzieci, które częściej doświadczały i/lub będą doświadczać strategii indukcyjnych, rozwinęły bądź rozwiną dojrzałą moralność, co oznacza opieranie się na wewnętrznych standardach moralnych w sytuacjach społecznych (internalizacja norm moralnych). Natomiast $\mathrm{u}$ tych dzieci, których rodzice lub ich partnerzy stosują częściej strategię przejawiania siły i/ lub wycofywania miłości, może wykształcić się taka orientacja moralna, która oparta będzie na strachu i chęci uniknięcia kary. Dzieci bazowałyby zatem na standardach zewnętrznych, a nie wewnętrznych.

Wspomniano wyżej, iż niektórzy badacze zwracają szczególną uwagę m.in. na indywidualne cechy dzieci w kontekście ich rozwoju moralnego i elastyczność rodziców (Kochańska, 1991; Grusec, Goodnow, 1994, za: Schaffer, 1996, s. 345). Warto w tym kontekście zwrócić uwagę, iż niekiedy także badani rodzice, opisując własne zachowania, zwracali uwagę na cechy indywidualne dzieci. Wyjaśniali, iż dostosowują swoje działania do konkretnej sytuacji. Ilustruje to fragment: „W przypadku, gdy np. dziecko jest bardzo zmęczone lub nie widzimy same już sensu skłonienia dziecka do jakiegoś zachowania, odpuszczamy" (Badany 7). Rodzic wykazuje się tu elastycznością, bierze pod uwagę naturę dziecka bądź jego stan fizyczny.

\section{Dyskusja}

Intelektualizm etyczny głosi, iż postępowanie moralne człowieka zależy od jego wiedzy na temat tego, co jest dobre, a co złe. Jeśli ktoś postępuje źle, oznacza to, iż jego wiedza na temat dobra jest ograniczona. Powszechnie uznaje się, iż to utożsamienie wiedzy i poznania (episteme) z cnotą (arete) pochodzi od Sokratesa. Sądził on, iż ,jest to jedno i to samo wiedzieć, co jest sprawiedliwe i być sprawiedliwym" (Tatarkiewicz, 2002, s. 74). Jak zauważa Władysław Tatarkiewicz, „wyłania się stąd proste wskazanie życiowe: należy szukać wiedzy, a kto może, powinien i innych wiedzy uczyć" (Tatarkiewicz, 2002, s. 75). $\mathrm{Z}$ przedstawionego powyżej przeglądu badań nad strategiami rodzicielskimi wynika, iż podawanie dziecku jasnych reguł i zasad postępowania, jak również konsekwencji określonego zachowania, stosowanie strategii indukcyjnej, szczególnie „zorientowanej na innych”, przyczynia się do rozwoju kompetencji prospołecznych i dojrzałości moralnej (internalizacji norm moralnych). Być może słuszne były poglądy Sokratesa dotyczące konieczności posiadania wiedzy na temat tego, co jest cnotliwe, aby w zgodzie z cnotą postępować. W ujęciu Hoffmana wiedza taka musi zostać w odpowiedni sposób przekazana, aby została zinternalizowana. Zatem tylko takie czynienie dobra, które wypływa 
z wewnętrznych standardów, świadczy o dojrzałości moralnej, a nie takie, które jest rezultatem strachu przed karą.

W kontekście omawianego przedmiotu badania warto zwrócić uwagę na problem tożsamości seksualnej rodziców, a także wieku dzieci. Większość badanych rodziców przed wejściem w związek z osobą tej samej płci żyła w związkach heteroseksualnych i z nich rodziły się dzieci i w nich także były wychowywane i socjalizowane. Wiek dzieci wahał się między 2,5 a 17 lat. Dwoje dzieci było wychowywanych od urodzenia przez osoby tej samej płci (biologicznej lub psychicznej) (Badany 1 i 7). Jedno dziecko wychowywane było bez ojca, a od 7 roku życia w związku osób tej samej płci (matka i jej partnerka) (Badany 6). Pozostałe dzieci wychowywane były zarówno przez nieheteroseksualnego rodzica (i czasami także jego partnera/kę), jak i heteroseksualnego, np. opieka naprzemienna (Badani 2, 3, 4, 5). Zatem większość dzieci badanych wychowywana była zarówno przez ojca jak i przez matkę, często jednocześnie przez ich homo- bądź heteroseksualnych partnerów. Są to zatem zmienne zakłócające, z powodu których nie można określić związku między tożsamością seksualną rodziców czy charakterem związku (jednopłciowy) a stosowanymi strategiami dyscyplinowania dziecka. Zastanawiać może także to, czy w ogóle istnieje (może istnieć) związek między rozwojem moralnym dzieci a „płciowym” charakterem związku. Jednak mimo znacznej ilości badań prowadzonych od lat 70. XX wieku, nadal istnieje wiele obaw społecznych dotyczących kompetencji rodzicielskich osób nieheteroseksualnych. Katarzyna Bojarska i Robert Kowalczyk zauważaja, iż „błędy wychowawcze popełnione przez konkretnych rodziców heteroseksualnych w społecznym odczuciu świadczą o złym rodzicielstwie tych konkretnych rodziców, lecz popełnione przez konkretnych rodziców LGB są postrzegane jako dowód niezdolności do rodzicielstwa całej populacji” (Bojarska, Kowalczyk, Lew-Starowicz, Skrzypulec, 2010, s. 57).

Zarówno z powodu tej nieuzasadnionej ekstrapolacji, jak i wspomnianego wyżej niepodejmowania zagadnienia strategii dyscyplinowania dzieci w historii badań nad rodzicielstwem gejów i lesbijek, warto, zdaniem autorki pracy, problem ten eksplorować. Włączenie tej zmiennej do badań m.in. nad rozwojem dzieci wychowywanych w związkach jednopłciowych dostarczy szerszej perspektywy w kontekście zależności między pewnymi obszarami rozwoju dzieci a determinującymi go czynnikami. Pozwoli także, jak wskazuje Rudolph H. Schaffer, na lepsze poznanie i zrozumienie osób, które były w określony sposób socjalizowane. Jest to także istotne ze względu na wspomnianą powszechność i częstotliwość tego typu oddziaływań wychowawczych i wykazywany 
w literaturze przedmiotu związek między technikami dyscyplinowania dziecka a kierunkiem rozwoju moralnego, jak również innymi konsekwencjami rozwojowymi np. rozwojem psychoseksualnym (Izdebski,1992).

\section{Bibliografia}

Baptist J. A., Allen K. R. (2008), A Family's Coming Out Process: Systematic Changes and Multiple Realities, "Contemporary Family Therapy", 30, 92-110.

Baumrid D. (1971), Current Patterns of parental authority. Developmental Psychology Monographs, 4, 1-101.

Baumrid D. (1978), Parental disciplinary patterns and social competence in children, "Youth \& Society", 9, 239-276.

Bigner J. J., Jacobsen R. B. (1989), Parenting behaviors of homosexual and heterosexual fathers, "Journal of Homosexuality", 18:173-186.

Bojarska K., Kowalczyk R. (2010), Homoseksualność i społeczeństwo, [w:] Z. Lew-Starowicz, V. Skrzypulec (red.), Podstawy seksuologii, Wydawnictwo Lekarskie PZWL, Warszawa.

Bos H. M. W., Balen F., Boom D. C. (2005), Lesbian family and family functioning: an overview, "Patient Education and Counseling", 59.

Bozett F. W. (1980), Gay Fathers: How and Why They Disclose Their Homosexuality to Their Children, "Family Relations", Vol. 29, No. 2.

Bozett F. W. (1987), Gay and Lesbian Parents, Praeger, New York.

Bozett F. W. (1988), Social control of identity by children of gay fathers, "Western Journal of Nursing Research", 10, 550-565.

Breawaes A., Devroey P., Helmerhorst F. M., van Hall E. C., Ponjaert I. (1995), Lesbian mothers who conceived after donor insemination: a follow-up study, "Human Reproduction", 10, 2731-2735.

Breawaes A., Ponjaert I., van Steirteghem A. C., Devroey P. (1993), Children from anonymous donors: an inquiry into homosexual and heterosexual parents'attitudes, "Journal of Psychosomatic Obstetrics \& Gynecology", 14, 23-35.

Brewaeys A., Ponjaert I., Hall E. V., Golombok S. (1997), Donor insemination: Child development and family functioning in lesbian mother families, "Human Reproduction", 12, 1349-1359.

Chan R. W., Raboy B., Patterson C. J. (1998), Psychosocial adjustment among children con- 
Małgorzata Kowalska Strategie dyscyplinowania dzieci stosowane przez rodziców...

ceived via donor insemination by lesbian and heterosexual mothers, "Child Development", 69, 443-457.

Chirrey D. A., (2003), "I hereby come out": What sort of speech act is coming out?, "Journal of Sociolinguistics", 7/1, 24-37.

Darling N., Steinberg L. (1993), Parenting style as context: An integrative model, "Psychological Bulletin”, 113, 487-496.

Eisenberg, N., Morris, A. S. (2001), The origins and social significance of empathy-related responding, "Social Justice", 14, 95-120.

Gartell N., Banks A., Hamilton J., Reed N., Bishop H., Rodas C. (1999), The National Lesbian Family Study: 2. Interviews with Mothers of Toddlers, "American Journal of Orthopsychiatry", 69(3), 362-369.

Gartell N., Banks A., Reed N., Hamilton J., Rodas C., Deck A. (2000), The National Lesbian Family Study: 3. Interviews with Mothers of Five-Year-Olds, "American Journal of Orthopsychiatry", 70(4), 542-548.

Gartell N., Hamilton J., Banks A., Mosbacher D., Reed N., Sparks C. H., Bishop H. (1996), The National Lesbian Family Study: 1. Interviews with prospective mothers, "American Journal of Orthopsychiatry", 66, 272-281.

Gershon T. D., Tschann J. M., Jemerin J. M. (1999), Stigmatization, self-esteem, and coping among the adolescent children of lesbian mothers, "Journal of Adolescent Health", 24, $437-445$.

Golombok S. (2002), Why I study... lesbian mothers?, "The Psychologist”, Vol. 15, No. 11.

Golombok S., Perry B., Burston A., Murray C., Mooney-Somers J., Stevens M., Golding J. (2003), Children With Lesbian Mothers: A Community Study, "Developmental Psychology", Vol. 39, No.1.

Golombok S., Spencer A., Rutter M. (1983), Children in lesbian and single parent household: psychosexual and psychiatric appraisal, "Journal of Child Psychology and Psychiatry", 24, 551-572.

Golombok S., Tasker F. (1996), Do Parents Influence the Sexual Orientation of Their Children? Findings From a Longitudinal Study of Lesbian Families, "Development Psychology", 32 (1), 3-11.

Golombok S., Tasker F. (1997), Children Raised in Fatherless Families from Infancy: Family Relationships and the Socioemotional Development of Children of Lesbian and Single Heterosexual Mothers, "Journal of Child Psychology \& Psychiatry \& Allied Disciplines", 38(7), 783-791. 
Gottman J. S. (1990), Children of gay and lesbian parents, [w:] F. W. Bozett I M. B. Sussman (eds.), Homosexuality and family relations, 177-196, Harrington Park, New York

Green R. (1978) Sexual identity of 37 children raised by homosexual or transsexual parents, "The American Journal of Psychiatry”, vol. 135, 692-697.

Green R., Mandel J., Hotveld M., Gray J., Smith L. (1986), Lesbian mothers and their children: a comparison with solo parent heterosexual mothers and their children, "Archives of Sexual Behavior", 15, 167-184.

Harris M. B., Turner P. H. (1985), Gay and lesbian parents, “Journal of Homosexuality”, 12, $101-113$

Hoeffer B. (1981), Children's acquisition of sex-role behavior in lesbian-mother families, "American Journal of Orthopsychiatry", 51, 536-544.

Hoffman L. M. (1963), Parent discipline and the child's consideration for others, "Child Development", 34, 573-588.

Hoffman L. M. (1970), Conscience, personality, and socialization techniques, "Human Development", 23, 90-126.

Hoffman M. L. (2006), Empatia i rozwój moralny, Gdańskie Wydawnictwo Psychologiczne, Gdańsk.

Hoffman M. L., Saltzstein H. D. (1967), Parent discipline and the child's moral development, "Journal of Personality and Social Psychology", 5, 45-57.

Hotveld M., Mandel J. (1982), Children of lesbian mothers, [w:] P. W. Weinrich, J. Gonsiorek, M. Hotveld, (eds.), Homosexuality: Social, Psychological and Biological Issues, Beverly Hills, Sage, 275-285.

Huggins S. (1989), A comparative study of self esteem of adolescent children of divorced lesbian mothers and divorced heterosexual mothers, [w:] F. W. Bozett (red.), Homosexuality and the Family, Harrington Park, New York, 123-135.

Izdebski Z. (1992), Seksualizm dzieci i młodzieży w Polsce: raport z badań, Wyd. WSP, Zielona Góra.

Javaid G. A. (1993), The children of homosexual and heterosexual single mothers, "Child Psychiatry and Human Development", 23, 235-248.

Joos K. E., Broad K. L. (2007), Coming Out of the Family Closet: Stories of Adult Women with LGBTQ Parent(s), "Qualitative Sociology”, 30, 275-295.

Kirkpatrick M., Smith C. i Roy R. (1981), Lesbian mothers and their children: A comparative survey, "American Journal of Orthopsychiatry", 51, 545-551. 
Małgorzata Kowalska Strategie dyscyplinowania dzieci stosowane przez rodziców...

Koepke L., Hare J., Moran P. B. (1992), Relationship Quality in a Sample of Lesbian Couples with Children and Child-Free Lesbian Couples, "Family Relations", 41 (2), 224-229.

Kuvulanka K. A., Goldberg A. E. (2009), “Second Generation” Voices: Queer Youth with Lesbian/Bisexual Mothers, "Journal of Youth and Adolescent", 38, 904-919.

Lewin E., Lyons T. A. (1982), Everything in its place. The coexistence of lesbianism and motherhood, [w:] P. W. Weinrich, J. Gonsiorek, M. Hotveld, (eds.), Homosexuality: Social, Psychological and Biological Issues, Sage, Beverly Hills, 249-273.

Lewis K. G. (1980), Children of lesbians: their point of view, "Social Work” (May), 198-203.

Lewis K. G. (1990), Children of lesbians: their point of view, "Social Work", 25, 193-198.

Maccoby E. E., Matrin J. A. (1983), Socialization in the context of the family: Parent-child interaction, [w:] E. M. Hetherington (ed.), Handbook of child psychology, 4. Socialization, personality, and social interaction, Wiley, New York.

McCandlish B. M. (1987), Against all odds: Lesbian mother family dynamics, [w:] F. W. Bozett (ed.), Gay and Lesbian Parents, Praeger, London.

Miller B. (1979), Gay Father and Their Children, "The Family Coordinator", Vol. 28, No. 4, s. 544-552.

Miller J., Jacobson R., Bigger J. (1981), The child's home environment for lesbian vs. heterosexual mothers. A neglected area of research, "Journal of Homosexuality", 7, 49-56.

Morris J. F., Balsam K. F., Rothbum E. D. (2002), Lesbian and bisexual mothers and nonmothers: demographics and the coming-out process, "Journal of Family Psychology", $16,144-156$.

Mucklow B., Phelan G. (1979), Lesbian and traditional mothers'responses to child behavior and self concept, "Psychological Report", 44, 880-2.

O'Connel A. (1993), Voices from the heart: The developmental impact of a mother's lesbianism on her adolescent children, Smith College Studies in Social Work, 63, 281-299.

Patterson C. J. (1995), Families of the baby boom: Parents division of labor and children's adjustment, "Developmental Psychology", 31, 115-123.

Prokopowicz P. (2008), Psychologiczne, spoleczne oraz prawne aspekty wychowywania dzieci przez pary homoseksualne, (red.), K. Slany, B. Kowalska, M. Śmietana, Zakład Wydawniczy NOMOS, Kraków.

Rand C., Graham D., Rawlings E. (1982), Psychological health and factors the court seeks to control in lesbian mother custody trails, "Journal of Homosexuality", 8, 27-39.

Rubacha K. (2008), Metodologia badań nad edukacja, Wyd. Akademickie i Profesjonalne, Warszawa. 
Schaffer H. R. (1996), Rozwój społeczny. Dzieciństwo i młodość, Wyd. Uniwersytetu Jagiellońskiego, Kraków.

Słownik Socjologii Jakościowej (2012), (red.) K. T. Konecki, P. Chomczyński, Wyd. Difin, Warszawa.

Spera C. (2005), A Review of the Relationship Among Parenting Practices, Parenting Styles, and Adolescent School Achievement, "Educational Psychology Review", Vol. 17, No. 2, 125-146.

Stafford L., Bayer C. L. (1993), Interaction between parents and children, Newbury Park, CA: Sage.

Steckel A. (1987), Psychological development of children of lesbian mothers, [w:] F. W. Bozzet (ed.), Gay and lesbian parents, Praeger, London.

Tasker F. L, Golombok S. (1997), Growing Up in a Lesbian Family. Effects on Child Development, The Guilford Press, New York-London.

Tasker F. L. (2005), Lesbian Mothers, Gay Fathers, and Their Children: A Review, "Developmental And Behavioral Pediatrics", Vol. 26, No. 3.

Tasker F., Golombok S. (1995), Adult raised as children in lesbian families, “American Journal of Orthopsychiatry", 65, 203-215.

Tatarkiewicz W. (2002), Historia filozofii. Tom pierwszy. Filozofia starożytna i średniowiecz$n a$, Wyd. Naukowe PWN, Gdańsk.

Tomalski P. (2007), Nietypowe rodziny. O parach gejów i lesbijek oraz ich dzieciach z perspektywy teorii przywiazania, Wydawnictwo Uniwersytetu Warszawskiego, Warszawa.

Vanfraussen K., Ponjaert-Kristoffersen I., Brewaeys A. (2001), An attempt to reconstruct children's donor concept: a comparison between children's and lesbian parents ' attitudes toward donor anonymity, "Human Reproduction", 16(9), 2019-2025.

Vanfraussen K., Ponjaert-Kristoffersen I., Brewaeys A. (2002), What does it mean for youngsters to grow up in a lesbian created by means of donor insemination?, "Journal of Reproductive and Infant Psychology", 20, 237-252.

Vanfraussen K., Ponjaert-Kristoffersen I., Brewaeys A. (2003), Family functioning in lesbian families created by donor insemination, "American Journal of Orthopsychiatry", 73, 78-90.

Weeks R. B., Derdeyn A. P. i Langman M. (1975), Two cases of children of homosexuals, "Child Psychology and Human Development", 6, 26-32.

Wyers N. L. (1987), Homosexuality in the family: lesbian and gay spouses, "Social Work", $32,143-148$. 